Theranos in Palo Alto, California, promised to upend medicine with a device that can perform hundreds of diagnostic tests on just a few drops of blood. 23andMe, in Mountain View, California, sells genetic tests directly to consumers. Both are led by charismatic female founders: Elizabeth Holmes at Theranos and Anne Wojcicki at 23andMe. Both want to revolutionize the health-care industry and argue that patients should have access to their data. They have strong backing from Silicon Valley investors, and were hyped early on: a US\$9-billion valuation for Theranos, and lavish parties with media tycoons for 23andme.

But both have seen their bubbles burst. On 16 October, The Wall Street Journal reported that the Theranos technology was not working as billed, and that the firm was using conventional machines to perform most of its tests. The company has disputed some of the article's claims. Holmes says that the company is now in a "pause period" because of scrutiny from US regulators.

23andMe's bubble burst in November 2013, when the US Food and Drug Administration (FDA) banned the inclusion of medically relevant results in the company's consumer genetic tests. On 21 October, however, 23 andMe relaunched consumer genetic tests that give a limited amount of medical information, with FDA approval. The new tests offer information for 36 diseases about a customer's status as a 'carrier' of genetic glitches that could cause disease if passed down through their children.

Theranos could learn a lot from how 23andMe returned to the regulators' good graces. 23andMe has always been fairly open about its science; it publishes research papers in peer-reviewed journals and collaborates with scientists. Theranos, by contrast, has been tightlipped about its data. Apart from detailed data for one herpesvirus test, approved by the FDA in July, the company has published only aggregate test performances on its website, not the primary data.

23 andMe says that coming back from its early mistakes with

the FDA was an arduous process - requiring it to hire staff with expertise in health regulation and to compile detailed dossiers of data to prove that its tests work as advertised. The company previously had been slow to respond to the FDA's entreaties - and that tonedeafness seems to have been part of the reason that the agency eventually cracked down.

These experiences do not mean that health care cannot be disrupted. Indeed, 23 andMe is the first company to gain FDA

"Time and again, new health-care firms are forced to realize that it helps no one to be secretive with data." disease. And the new test package costs US\$199 compared with $\$ 99$ before the ban.

23andMe has also moved to make itself into a more conventional pharmaceutical firm. In March, it hired former Genentech executive Richard Scheller to lead a drug-development arm. If you can't beat them, join them.

Time and again, new health-care firms are forced to realize that it helps no one to be secretive with data. Even if it turns out that the Theranos technology does not work as well as advertised, the company would hardly be the first to find itself in that situation. Releasing more information earlier might have forced Theranos to confront shortcomings. Instead, it finds itself trying to recover from a regulatory and public-relations hole. This is not an insurmountable situation, as 23andMe knows. The challenge now is for Theranos to show us the data.

\section{Ghost story}

The problem of abandoned fishing gear and its effects on marine life deserve greater attention.

$\mathrm{H}$ ere's a horror story for Halloween. Right now, in unlit waters across the world, fish, crabs and other marine life are being drawn into nets and traps by the dead and decomposing bodies of their comrades. There they will stick, struggle and tangle, until they, too, become unwitting bait and continue the circle of death. Old fishing nets, you see, never die. They just drift away.

The problem of ghost fishing, as it is known, goes largely unnoticed, but some of this dead gear catches and kills more sea life than it did when it was alive and in active use. Reliable data on the scale of the problem are scarce, but some estimates suggest that the nets can remove up to $30 \%$ of the landed catch of certain fish species.

It is said that we know more about the surface of the Moon than about the bed of the sea. Perhaps we are afraid of what we will find there if we look too hard: wrecks of gill nets, entangling nets, pelagic and demersal longlines, lobster and crab pots, seine nets, trawl-net fragments and the sinister-sounding fish aggregating devices - buoys or floats, tethered to concrete blocks, around which fish tend to congregate.

Some of this fishing gear is lost and some is abandoned in rough weather. Much is simply discarded by fishers with nowhere to stow it, who are fishing where they should not be, or who just want to avoid the expense and hassle of disposing of it properly. Most of this gear sinks to the bottom. It becomes a hazard, to boats and divers. And much of it continues to catch and kill, long after it has been forgotten.
Take the coastline of Louisiana, a US state that is home to its fair share of spooky tales. Each of the 1,800 or so professional crab fishers who work there loses about 250 traps every year. Each abandoned trap, a crude wire cage, is reckoned to catch and kill a blue crab (Callinectes sapidus) every two weeks. That is 12 million crabs a year, or 2 million kilograms of crab meat - about US\$4-million worth - along a single stretch of coastline (J. A. Anderson and A. B. Alford Mar. Pollut. Bull. 79, 261-267; 2014). Ghost crab traps snare other creatures too: spotted sea trout, diamondback terrapins and river otters among them.

Although the world organizes regular conferences to address the threat of orbiting space junk, action on the danger of ghost fishing tends to be left to volunteers. Louisiana law allows a ten-day period each year when citizens can drag derelict fishing gear from the water. In two sessions - 2012 and 2013 - volunteers recovered a total of 3,607 ghost crab traps. More than $65 \%$ of them had caught something. The actions of such volunteers are admirable but they are not enough. The fishing industry and those who profit from it must take more responsibility.

Earlier this year, Eric Gilman, a fisheries scientist at Hawaii Pacific University in Honolulu, published a survey of international efforts to track and control ghost fishing (E. Gilman Mar. Policy 60, 225-239; 2015). Of the 19 global and regional bodies (from the International Whaling Commission down to the South East Atlantic Fisheries Organization) that he identified as being in a position to intervene, just 4 had an explicit mandate to monitor and reduce the problem. Almost half did not even collect data on lost gear. The 12 organizations that have introduced measures to help prevent and reduce ghost fishing have not used all the options available to them.

All ghost stories are more chilling in the dark. $\rightarrow$ NATURE.COM To comment online, click on Editorials at: go.nature.com/xhunqv The problem of abandoned, lost and discarded fishing gear deserves more attention and more action. For unlike many gruesome stories you will hear this weekend, this one is true. 